Diabetologia (1994) 37: 381-387

\title{
Diet, cow's milk protein antibodies and the risk of IDDM in Finnish children
}

\author{
S. M. Virtanen ${ }^{1.2}$, T. Saukkonen ${ }^{2}$, E. Savilahti ${ }^{3}$, K. Ylönen ${ }^{1}$, L. Räsänen ${ }^{1}$, A. Aro ${ }^{4}$, M. Knip ${ }^{6}, J_{\text {Tuomilehto }}^{5}$, \\ H.K. A Kerblom ${ }^{2}$ and the Childhood Diabetes in Finland Study Group** \\ ${ }^{1}$ Division of Nutrition, Department of Applied Chemistry and Microbiology and the Children's Hospital, ${ }^{2}$ Second and \\ ${ }^{3}$ First Departments of Pediatrics, University of Helsinki, Helsinki, Finland \\ Departments of ${ }^{4}$ Nutrition and ${ }^{5}$ Epidemiology and Health Promotion, National Public Health Institute, Helsinki, Finland \\ ${ }^{6}$ Department of Paediatrics, University of Oulu, Oulu, Finland
}

\begin{abstract}
Summary Associations of infant feeding patterns and milk consumption with cow's milk protein antibody titres were studied in 697 newly-diagnosed diabetic children, 415 sibling-control children and 86 birth-dateand sex-matched population-based control children in the nationwide "Childhood Diabetes in Finland" study. IgA and IgG antibody titres to the proteins of cow's milk formula, BLG and BSA, and IgM antibody titres to cow's milk formula proteins were measured by ELISA. Several inverse correlations were observed between the duration of breast-feeding or age at introduction of dairy products and antibody titres, and positive correlations were observed between milk consumption and antibody titres in all three populations studied. Multivariate analyses which included the infant feeding variables, milk consumption and current age simultaneously showed that the earlier the introduction of
\end{abstract}

dairy products and the greater the consumption of milk was, the higher several antibody titres were. High IgA antibody titres to cow's milk formula were associated with a greater risk of IDDM both among diabeticpopulation-control and diabetic-sibling-control pairs when adjusted for other cow's milk antibody titres, dietary variables and in diabetic-sibling-control pairs also for ICA. The results suggest that young age at introduction of dairy products and high milk consumption during childhood increase the levels of cow's milk antibodies and that high IgA antibodies to cow's milk formula are independently associated with increased risk of IDDM. [Diabetologia (1994) 37:381-387]

Key words Infant feeding, dairy products, cow's milk protein antibodies, IDDM, childhood, islet cell antibodies, insulin autoantibodies.
Observations on the possible inverse association between duration of breast-feeding or proportion of breast-fed children and the risk of IDDM have been conflicting $[1,2]$. Several studies have suggested that an

* See Acknowledgements

Received: 5 August 1993

and in revised form: 22 October 1993

Corresponding author: Dr. S. M. Virtanen, Division of Nutrition, Department of Applied Chemistry and Microbiology, University of Helsinki, P.O. Box 27, SF-00014 University of Helsinki, Finland

Abbreviations: IDDM, Insulin-dependent diabetes mellitus; BLG, betalactoglobulin; BSA, bovine serum albumin; ICA, islet cell antibodies; IAA, insulin autoantibodies; OR, odds ratio; $\mathrm{CI}$, confidence interval. early introduction of dairy products or other foods could be related to an increased risk of IDDM [3-7]. A detailed study of infant feeding patterns indicated that the age at introduction of dairy products had the closest association with the risk of IDDM when the duration of both overall and exclusive breast-feeding was taken into account [8]. This is in accordance with previous studies $[9,10]$ which showed that the early introduction of dairy products increased the incidence of diabetes in diabetes-prone Bio Breeding rats. Further, increased levels of antibodies to cow's milk formula, BLG and BSA have been observed in newly-diagnosed diabetic children [5, 11-13]. Recently, high BLG IgA antibody titres were suggested as a risk determinant of IDDM independently of early formula feeding, although early introduction of formula also remained a risk determinant [5].

The present study evaluates in a nationwide study the associations of early infant feeding patterns and 
milk consumption in childhood with cow's milk protein antibody titres. Further, the associations of these dietary variables and cow's milk antibody titres with the risk of IDDM were studied in newly-diagnosed diabetic children, unrelated siblings of diabetic children and population-based control children.

\section{Subjects and methods}

In the nationwide "Childhood Diabetes in Finland" study on genetic and environmental determinants of childhood IDDM [14] detailed data were collected on infant feeding patterns and later childhood diet, and blood samples were collected for analyses of e.g. serum cow's milk antibodies, conventional cytoplasmic ICA, and IAA. During the study period from September 1986 to April 1989, 801 families with a newly-diagnosed child aged 0 to 14 years were invited to participate in the study. Of the diabetic children, $94 \%$ participated in the dietary study and a blood sample was obtained in $88 \%$. All the 3- to 19-year-old siblings of the diabetic subjects were invited to the study. Of these, $82 \%$ participated in the dietary study and a blood sample was obtained in $82 \%$. One non-diabetic sibling unrelated to the proband (from different family) matched for birth year (within 2 years) and sex was selected from the families participating in the study. Siblings older than 14 years were excluded from the present analyses. In addition, birth-date- and sex-matched random population-based control children were collected from the Finnish national population registry for the 121 diabetic children younger than 7 years who were diagnosed from May 1988 to April 1989 [3]. Of these population-control children, $85 \%$ participated in the dietary study and a blood sample was obtained in $87 \%$. The final population of the present study comprises 697 diabetic children aged 0 to 14 years, 415 sibling-control children aged 3 to 14 years and 86 population-control children aged 0 to 6 years. They form 415 diabetic-sibling-control pairs (aged 3 to 14 years) and 86 diabetic-population-control pairs (aged 0 to 6 years). The ethical committees of all the participating hospitals have approved the study protocol. Informed consent was obtained from the participants.

Dietary, sociodemographic, and neonatal data were collected using structured questionnaires $[3,6]$. The dietary variables used in the present study were the duration of overall (total) and exclusive (no other foods than breast-milk) breastfeeding, the age at introduction of dairy products (infant formulas, cow's milk, yogurt, and other cow's milk products) and the amount of milk and sour milk (in glasses, 1 glass $=180 \mathrm{ml}$ ) consumed daily before taking part in the study and for diabetic children before any symptoms of diabetes had appeared. The neonatal variables used in this study were birth weight, birth order, and prematurity of the child. Equal proportions of diabetic $(12 \%)$, sibling-control (15\%) and population-control children $(15 \%)$ were reported to have been born pre-term. Neither the mean birth weight of diabetic $(3,565 \mathrm{~g})$, sibling-control $(3,590 \mathrm{~g})$ nor population-control children $(3,607 \mathrm{~g})$ differ from each other. There were fewer diabetic children than sibling-control children whose birth order exceeded three ( $4 \%$ vs $8 \%, p=0.01)$. Likewise, a smaller proportion of diabetic children than populationcontrol children had a birth order exceeding three $(1 \%$ vs $8 \%$, $p=0.01$ ). A smaller proportion of mothers of diabetic children compared with mothers of population-control children had been educated longer than 13 years $(26 \%$ vs $42 \%, p=0.03)$. The length of the mother's education did not differ between diabetic and sibling-control children. Equal proportion of diabetic children $(10 \%)$, sibling-control children $(12 \%)$ and population- control children $(12 \%)$ had a history of chronic allergic symptoms. A history of acute gastroenteritis during the year preceding the study was more frequent among diabetic than population-control children ( $46 \%$ vs $30 \%, p=0.04$ ), whereas there was no difference between diabetic and sibling-control children (36\% vs $34 \%$ ).

Cow's milk formula, BLG and BSA antibodies in serum samples were measured by solid phase ELISA as described previously in detail $[13,15]$. Briefly, diluted serum samples were added to microtitre plates in parallel in wells coated with antigen and in non-coated wells, followed by alkaline phosphatase conjugated swine anti-human IgG or IgA or IgM (Orion Diagnostica, Helsinki, Finland). Diluted (1:500), defatted adapted liquid cow's milk formula (Tutteli; Valio Ltd, Helsinki, Finland) was used for coating in cow's milk antibody assay and these antibodies are referred to here as cow's milk formula antibodies. Absorbance of the non-coated well was subtracted from the mean absorbance of the antigen-coated wells to obtain specific absorbance. A dilution series of a standard serum with a very high antibody titre was included in each plate, and results were expressed as percent of the standard.

ICA were determined by a standard indirect immunofluorescence method performed on sections of frozen human group $\mathrm{O}$ pancreas. The antibodies were identified by the conventional indirect method [16] as described in detail earlier [17]. The levels of ICA were analysed semiquantitatively using a scale from 0 to $3(0=$ negative, $1=$ weakly positive, $2=$ positive, $3=$ strongly positive). End-point dilution titres were examined in samples from 86 diabetic children and were expressed in Juvenile Diabetes Foundation (JDF) units relative to an international reference standard [18]. Of the diabetic children $79 \%$, of the sibling-control children $5 \%$ and of the population-control children $0 \%$ were positive for ICA. IAA were measured by a modification of the liquid phase radioimmunoassay [19].

\section{Statistical analysis}

All comparisons between diabetic and sibling-control children and between diabetic and population-control children were done with paired tests. The median values of the variables which were not normally distributed were compared with the sign test and the paired $t$-test was used for the normally distributed variables. Spearman's coefficients of correlation were calculated between cow's milk antibody titres (cow's milk formula, BLG and BSA) and dietary variables because the antibody titres were not normally distributed and logarithmic transformation did not normalize their distribution. Pearson's coefficients of correlation were calculated between $\log$-transformed IAA and quantitative ICA values and dietary variables. Partial correlations were used for adjustment for age. ORs ( $95 \%$ CIs) were used to estimate the associations of the dietary variables with the cow's milk antibody titres and to estimate the associations of the antibody titres and dietary variables with the risk of IDDM. Adjustment for the confounding variables was performed by conditional matched logistic regression. The cow's milk antibody titres were dichotomized using the values in the fourth quartile as positive to antibodies. The division into quartiles was done according to the levels in the population-control children when studying diabetic-populationcontrol pairs and according to the levels in the sibling-control children when studying diabetic-sibling-control pairs or when studying all diabetic children alone. The proportion of ICA positivity among cow's milk antibody positive and negative children was compared with the McNemar test. 
Table 1. Partial age-adjusted correlations of cow's milk antibody titres and IAA with dietary factors in 697 diabetic, 415 sibling-control and 86 population-control children

\begin{tabular}{|c|c|c|c|c|}
\hline & & $\begin{array}{l}\text { Duration of overall } \\
\text { breast-feeding } \\
r\end{array}$ & $\begin{array}{l}\text { Age at introduction } \\
\text { of dairy products } \\
\mathrm{r}\end{array}$ & $\begin{array}{l}\text { Current milk } \\
\text { consumption } \\
r\end{array}$ \\
\hline $\begin{array}{l}\text { Cow's milk } \\
\text { formula IgA }\end{array}$ & $\begin{array}{l}\text { Diabetic children } \\
\text { Sibling-control children } \\
\text { Population-control children }\end{array}$ & $\begin{array}{l}-0.24^{\mathrm{c}} \\
-0.32^{\mathrm{c}} \\
-0.27^{\mathrm{a}}\end{array}$ & $\begin{array}{l}-0.21^{\mathrm{c}} \\
-0.31^{\mathrm{c}} \\
-0.18\end{array}$ & $\begin{array}{l}0.11^{\mathrm{b}} \\
0.02^{\mathrm{a}} \\
0.22^{\mathrm{a}}\end{array}$ \\
\hline $\begin{array}{l}\text { Cow's milk } \\
\text { formula IgG }\end{array}$ & $\begin{array}{l}\text { Diabetic children } \\
\text { Sibling-control children } \\
\text { Population-control children }\end{array}$ & $\begin{array}{l}-0.15^{\mathrm{c}} \\
-0.25^{\mathrm{c}} \\
-0.13\end{array}$ & $\begin{array}{l}-0.14^{c} \\
-0.22^{c} \\
-0.14\end{array}$ & $\begin{array}{l}0.13^{\mathrm{c}} \\
0.05 \\
0.18\end{array}$ \\
\hline $\begin{array}{l}\text { Cow's milk } \\
\text { formula IgM }\end{array}$ & $\begin{array}{l}\text { Diabetic children } \\
\text { Sibling-control children } \\
\text { Population-control children }\end{array}$ & $\begin{aligned} & 0.08^{a} \\
- & 0.09 \\
- & 0.05\end{aligned}$ & $\begin{array}{r}0.06 \\
-0.08 \\
0.12\end{array}$ & $\begin{array}{r}0.02 \\
0.07 \\
-0.06\end{array}$ \\
\hline BLG IgA & $\begin{array}{l}\text { Diabetic children } \\
\text { Sibling-control children } \\
\text { Population-control children }\end{array}$ & $\begin{array}{r}-0.09^{\mathrm{a}} \\
0.02 \\
-0.28^{\mathrm{b}}\end{array}$ & $\begin{array}{l}-0.07 \\
-0.01 \\
-0.12\end{array}$ & $\begin{array}{r}0.01 \\
0.04 \\
-0.04\end{array}$ \\
\hline BLG IgG & $\begin{array}{l}\text { Diabetic children } \\
\text { Sibling-control children } \\
\text { Population-control children }\end{array}$ & $\begin{array}{c}-0.15^{\mathrm{c}} \\
-0.22^{\mathrm{c}} \\
0.08\end{array}$ & $\begin{array}{c}-0.10^{\mathrm{a}} \\
-0.20^{\mathrm{c}} \\
0.04\end{array}$ & $\begin{array}{r}0.04 \\
0.02 \\
-0.16\end{array}$ \\
\hline BSA IgA & $\begin{array}{l}\text { Diabetic children } \\
\text { Sibling-control children } \\
\text { Population-control children }\end{array}$ & $\begin{array}{l}-0.13^{\mathrm{b}} \\
-0.14^{\mathrm{b}} \\
-0.31^{\mathrm{b}}\end{array}$ & $\begin{array}{l}-0.10^{\mathrm{a}} \\
-0.12^{\mathrm{a}} \\
-0.19\end{array}$ & $\begin{array}{l}0.07 \\
0.12^{\mathrm{a}} \\
0.15\end{array}$ \\
\hline BSA IgG & $\begin{array}{l}\text { Diabetic children } \\
\text { Sibling-control children } \\
\text { Population-control children }\end{array}$ & $\begin{array}{l}-0.12^{\mathrm{b}} \\
-0.13^{\mathrm{a}} \\
-0.25^{\mathrm{a}}\end{array}$ & $\begin{array}{l}-0.11^{\mathrm{b}} \\
-0.18^{\mathrm{c}} \\
-0.16\end{array}$ & $\begin{array}{l}0.18^{c} \\
0.21^{c} \\
0.01\end{array}$ \\
\hline IAA & $\begin{array}{l}\text { Diabetic children } \\
\text { Sibling-control children } \\
\text { Population-control children }\end{array}$ & $\begin{array}{l}-0.00 \\
-0.03 \\
-0.23^{a}\end{array}$ & $\begin{array}{c}0.03 \\
0.01 \\
-0.27^{\mathrm{a}}\end{array}$ & $\begin{array}{l}0.04 \\
0.11^{\mathrm{a}} \\
0.06\end{array}$ \\
\hline
\end{tabular}

${ }^{\mathrm{a}} p<0.05,{ }^{\mathrm{b}} p<0.01,{ }^{\mathrm{c}} p<0.001$

\section{Results}

\section{Diet, cow's milk antibodies, ICA, and IAA}

Several associations were observed between the overall duration of breast-feeding, the age at introduction of dairy products, and current milk consumption and cow's milk antibody titres (Table 1 ). The correlations between the duration of exclusive breast-feeding and cow's milk antibody titres were similar to those of the age at introduction of dairy products (data not shown). IAA level correlated significantly with the duration of breast-feeding and with the age at introduction of dairy products only in population-control children when adjusted for current age (Table 1). In the subgroup of 0 to 6-year-old diabetic children, in whom quantitative measurement of serum ICA had been done $(n=86)$, no correlations were observed between ICA and the dietary variables. Current milk consumption correlated inversely with the duration of overall breast-feeding $(r=-0.15, p<0.001)$ and with the age at introduction of dairy products $(r=-0.12, p=0.003)$ in diabetic children but when adjusted for current age these correlations became non-significant. A greater proportion of ICA positive than ICA negative diabetic children were positive for cow's milk antibodies, the only excep- tions being BLG IgA and cow's milk formula IgM antibodies which were more frequently negative in ICA positive diabetic children $(p<0.001)$.

The only differences between diabetic and siblingcontrol children in infant feeding patterns were the shorter duration of overall breast-feeding of the diabetic children (median values 5 vs 6 months, $p=0.008$, respectively) and the greater proportion of diabetic children who had received dairy products by the age of 6 months $(75 \%$ vs $67 \%, p=0.01)$. At the time before diagnosis of diabetes diabetic children consumed the same amount of milk daily as sibling-control children (mean values for both groups 3.4 glasses) and population-control children (mean values 3.1 vs 2.8 glasses). A similar proportion of diabetic and siblingcontrol children ( $90 \%$ vs $88 \%$ ) and diabetic and population-control children ( $91 \%$ vs $94 \%$ ) consumed milk daily.

A positive history for allergic symptoms or gastroenteritis was not associated with the cow's milk antibody titres in the diabetic, sibling-control or population-control children. Cow's milk antibody titres of diabetic children who had a first degree relative with IDDM at the time of diagnosis of diabetes did not differ from those in other diabetic children. Full-term diabetic, sibling-control or population-control children 
Table 2. Adjusted ORs and $95 \%$ CIs separately for different cow's milk antibody titres (highest quartile) in diabetic children, sibling-control children and population-control children by duration of overall breast-feeding (breast-feeding, $\geq 4$ months),

age at introduction of dairy products (dairy products, $\geq 4$ months) and current milk consumption (current milk, $\geq 3$ glasses). All dietary variables were simultaneously included in each model. All models were adjusted for age

\begin{tabular}{|c|c|c|c|c|c|c|}
\hline & \multicolumn{2}{|c|}{$\begin{array}{l}\text { Diabetic children } \\
n=697\end{array}$} & \multicolumn{2}{|c|}{$\begin{array}{l}\text { Sibling-control children } \\
n=415\end{array}$} & \multicolumn{2}{|c|}{$\begin{array}{l}\text { Population-control children } \\
n=86\end{array}$} \\
\hline & $\overline{\mathrm{OR}}$ & $95 \% \mathrm{CI}$ & OR & $95 \% \mathrm{CI}$ & OR & $95 \% \mathrm{CI}$ \\
\hline $\begin{array}{l}\text { Cow's milk formula IgM } \\
\text { Breast-feeding } \\
\text { Dairy products } \\
\text { Current milk }\end{array}$ & $\begin{array}{l}0.98 \\
1.13 \\
1.61\end{array}$ & $\begin{array}{l}(0.53-1.84) \\
(0.61-2.08) \\
(0.96-2.68)\end{array}$ & $\begin{array}{l}0.81 \\
0.91 \\
0.76\end{array}$ & $\begin{array}{l}(0.39-1.70) \\
(0.43-1.89) \\
(0.45-1.29)\end{array}$ & $\begin{array}{l}0.32 \\
2.97 \\
0.70\end{array}$ & $\begin{array}{l}(0.02-4.28) \\
(0.32-28.0) \\
(0.25-1.96)\end{array}$ \\
\hline $\begin{array}{l}B L G \operatorname{Ig} G \\
\text { Breast-feeding } \\
\text { Dairy products } \\
\text { Current milk }\end{array}$ & $\begin{array}{l}0.55 \\
1.16 \\
1.35\end{array}$ & $\begin{array}{l}(0.33-0.94)^{\mathrm{a}} \\
(0.69-1.93) \\
(0.90-2.01)\end{array}$ & $\begin{array}{l}2.12 \\
0.30 \\
1.26\end{array}$ & $\begin{array}{l}(1.02-4.39)^{\mathrm{a}} \\
(0.15-0.63)^{\mathrm{a}} \\
(0.72-2.19)\end{array}$ & $\begin{array}{l}1.07 \\
3.78 \\
1.35\end{array}$ & $\begin{array}{l}(0.05-22.3) \\
(0.40-35.7) \\
(0.46-3.99)\end{array}$ \\
\hline $\begin{array}{l}B S A \operatorname{Ig} A \\
\text { Breast-feeding } \\
\text { Dairy products } \\
\text { Current milk }\end{array}$ & $\begin{array}{l}0.67 \\
0.82 \\
1.59\end{array}$ & $\begin{array}{l}(0.40-1.10) \\
(0.50-1.34) \\
(1.07-2.35)^{a}\end{array}$ & $\begin{array}{l}1.01 \\
0.63 \\
1.21\end{array}$ & $\begin{array}{l}(0.48-2.12) \\
(0.30-1.31) \\
(0.70-2.10)\end{array}$ & $\begin{array}{l}0.66 \\
0.66 \\
3.21\end{array}$ & $\begin{array}{l}(0.08-5.12) \\
(0.13-3.40) \\
(0.91-11.3)\end{array}$ \\
\hline $\begin{array}{l}\text { BSA IgG } \\
\text { Breast-feeding } \\
\text { Dairy products } \\
\text { Current milk }\end{array}$ & $\begin{array}{l}1.02 \\
0.73 \\
1.78\end{array}$ & $\begin{array}{l}(0.61-1.72) \\
(0.44-1.20) \\
(1.19-2.67)^{\mathrm{a}}\end{array}$ & $\begin{array}{l}0.69 \\
0.54 \\
2.90\end{array}$ & $\begin{array}{l}(0.32-1.50) \\
(0.25-1.17) \\
(1.52-5.56)^{a}\end{array}$ & $\begin{array}{l}1.04 \\
0.36 \\
0.81\end{array}$ & $\begin{array}{l}(0.14-7.79) \\
(0.07-1.81) \\
(0.27-2.38)\end{array}$ \\
\hline
\end{tabular}

${ }^{\mathrm{a}} p<0.05$ for significant $\mathrm{ORs}$ and their $95 \% \mathrm{CIs}$

did not differ from pre-term ones in their cow's milk antibody titres.

The associations between dietary variables and cow's milk antibodies were studied further by including simultaneously the overall duration of breast-feeding ( $\geq 4$ months), the age at introduction of dairy products ( $\geq 4$ months), current milk consumption ( $\geq 3$ glasses daily), and current age (continuous) in a logistic regression model explaining each cow's milk antibody titre in diabetic children, sibling-control children and population-control children (Table 2). In the diabetic children, the overall duration of breast-feeding was inversely associated with BLG IgG antibody titres, the age at introduction of dairy products inversely and current milk consumption positively with cow's milk formula IgA antibody titres, and current milk consumption positively with cow's milk formula IgG and BSA IgA and $\mathrm{IgG}$ antibody titres. In the sibling-control children, the age at introduction of dairy products was inversely associated with cow's milk formula IgA, BLG IgA and BLG IgG antibody titres, and current milk consump- tion positively with BSA IgG antibody titres. In addition, the duration of overall breast-feeding was positively associated with BLG IgG antibody titres in the sibling-control children. In the population-control children, current milk consumption was associated with increased titres of cow's milk formula $\operatorname{IgA}$ antibody.

\section{Risk of IDDM}

In univariate analyses most of the cow's milk antibodies were associated with the risk of IDDM both among diabetic-sibling-control pairs and among diabeticpopulation-control pairs (Table 3). When all the cow's milk antibodies were included in the logistic model at the same time, IgA antibodies to BSA (OR 1.59, 95\% CI 1.13-2.24) and BLG (OR 1.44, 95\% CI 1.03-2.02) and $\operatorname{IgM}$ antibodies to cow's milk formula (OR 0.62 , $95 \%$ CI $0.41-0.92$ ) were significantly associated with the risk of IDDM among diabetic-sibling-control pairs. 
Table 3. Unadjusted and adjusted ORs and 95\% CIs for risk of IDDM among diabetic-sibling-control pairs and diabetic-populationcontrol pairs

\begin{tabular}{|c|c|c|c|c|c|c|c|c|}
\hline & \multicolumn{8}{|c|}{ Risk of IDDM } \\
\hline & \multicolumn{4}{|c|}{ Diabetic vs sibling-control children $(n=830)$} & \multicolumn{4}{|c|}{ Diabetic vs population-control children $(n=172)$} \\
\hline & \multicolumn{2}{|c|}{ Unadjusted } & \multicolumn{2}{|c|}{ Adjusted $^{\mathrm{a}}$} & \multicolumn{2}{|c|}{ Unadjusted } & \multicolumn{2}{|c|}{ Adjusted $^{\mathrm{a}}$} \\
\hline $\begin{array}{l}\text { Overall breast-feeding } \\
\geq 4 \text { months }\end{array}$ & 0.82 & $(0.59-1.13)$ & 1.68 & $(0.33-8.72)$ & 0.54 & $(0.21-1.37)$ & 1.12 & $(0.25-5.00)$ \\
\hline $\begin{array}{l}\text { Supplementary milk } \\
\text { feeding } \geq 4 \text { months }\end{array}$ & 0.82 & $(0.60-1.13)$ & 0.44 & $(0.08-2.42)$ & 0.58 & $(0.30-1.14)$ & 1.01 & $(0.35-2.89)$ \\
\hline $\begin{array}{l}\text { Current milk consump- } \\
\text { tion } \geq 3 \text { glasses }\end{array}$ & 1.10 & $(0.80-1.51)$ & 2.33 & $(0.86-6.35)$ & 1.10 & $(0.60-2.00)$ & 0.95 & $(0.41-2.17)$ \\
\hline $\begin{array}{l}\text { Cow's milk formula } \\
\left.\text { - IgA ( } 4^{\text {th }} \text { quartile }\right) \\
\text { - } \operatorname{IgG}\left(4^{\text {th }} \text { quartile }\right) \\
-\operatorname{IgM}\left(4^{\text {th }} \text { quartile }\right)\end{array}$ & $\begin{array}{l}1.80 \\
1.49 \\
0.72\end{array}$ & $\begin{array}{l}(1.33-2.44)^{\mathrm{b}} \\
(1.09-2.05)^{\mathrm{b}} \\
(0.51-1.02)\end{array}$ & $\begin{array}{l}6.70 \\
1.83 \\
0.10\end{array}$ & $\begin{array}{l}(1.52-29.6)^{\mathrm{b}} \\
(0.60-5.56)^{\mathrm{b}} \\
(0.03-0.40)^{\mathrm{b}}\end{array}$ & $\begin{array}{l}3.08 \\
1.54 \\
0.81\end{array}$ & $\begin{array}{l}(1.59-5.97)^{\mathrm{b}} \\
(0.76-3.12) \\
(0.39-1.71)\end{array}$ & $\begin{array}{l}4.55 \\
0.70 \\
0.52\end{array}$ & $\begin{array}{l}(1.48-14.0)^{\mathrm{b}} \\
(0.22-2.29) \\
(0.19-1.45)\end{array}$ \\
\hline Positive ICA & 60.6 & $(25.0-147)^{\mathrm{b}}$ & 455 & $(56.6-3660)^{\mathrm{b}}$ & - & - & - & - \\
\hline
\end{tabular}

adjusted for all other variables in the table.

${ }^{\mathrm{b}} p<0.05$ for significant ORs and their $95 \% \mathrm{CIs}$

Among diabetic-population-control pairs only $\operatorname{IgA}$ antibodies to cow's milk formula (OR 3.63, $95 \%$ CI $1.36-9.70)$ remained significant when all the antibodies were included in the same model. When adjusted for all the other cow's milk antibodies, the overall duration of breast-feeding, age at introduction of dairy products, and current milk consumption, and in diabetic-siblingcontrol pairs also for ICA, IgA antibodies to cow's milk formula were significant among both diabetic-siblingcontrol pairs and diabetic-population-control pairs and IgM antibodies to cow's milk formula were inversely associated with the risk of IDDM among diabetic-sibling-control pairs (Table 3). When ICA was removed from this model only IgA antibodies to cow's milk formula remained significantly associated with an increased risk of IDDM (OR 1.83, 95\% CI 1.11-3.01) among diabetic-sibling-control pairs. The adjustment for length of mother's education ( $\leq 13$ years, $>13$ years $)$ or child's birth order $(\leq 3,>3)$ changed none of the results.

\section{Discussion}

Ingested cow's milk protein induces an immune response as early as during the first weeks of life [20]. Feeding practices affect the level of serum IgG cow's milk antibodies during the first 6 months, exclusively breast-fed infants having lower levels than cow's milk formula-fed infants or breast-fed infants who receive cow's milk supplementation [21-23]. However, the differences tend to diminish thereafter; e.g. at the age of 2.5 years no differences were found in cow's milk for- mula IgG antibody titres in healthy children breast-fed either longer or shorter than 5 months [22]. Introduction of cow's milk or cow's milk formula did not affect cow's milk formula or BLG IgA and IgM antibody levels either $[22,24]$. We observed in the population-control children inverse age-adjusted correlations between duration of overall breast-feeding and IgA antibody titres to cow's milk formula, BLG and BSA, and IgG antibody titres to BSA. Serum antibodies to cow's milk proteins are detectable even in healthy adults [25]; however, a quantitative relationship between these antibodies and milk consumption has not been demonstrated.

In a Swedish study it was observed that the longer the duration of breast-feeding or the later the introduction of formula feeding was, the lower the IgA antibody titres to cow's milk formula and IgG antibody titres to BLG were among diabetic and control children who were pooled in the correlation analyses [5]. Our study confirmed these findings. In addition, we found inverse age-adjusted correlations between these infant feeding variables and cow's milk formula IgG, BLG IgA, and BSA IgA and IgG antibodies and positive correlations between current milk consumption and IgA and IgG antibody titres to cow's milk formula and BSA in either diabetic children, sibling-control children or population-control children. Multivariate analyses which included the two infant feeding variables and current milk consumption simultaneously showed that the earlier dairy products were introduced to the child and the greater the consumption of milk was, the higher cow's milk antibody titres were both in the diabetic children and sibling-control children. 
We have recently shown in the "Childhood Diabetes in Finland" study population that an early age at introduction of dairy products was associated with an increased risk of IDDM independently of the duration of breast-feeding [8]. The newly-diagnosed diabetic children had higher serum IgA and IgG antibody titres to cow's milk formula, BLG and BSA compared with agematched population-control children or non-diabetic sibling-control children [13; and unpublished data]. Of the various cow's milk antibodies, $\operatorname{IgA}$ antibodies to BSA and BLG were, independently of other cow's milk antibodies, associated with an increased risk of IDDM among diabetic-sibling-control pairs, whereas $\operatorname{IgM}$ antibodies to cow's milk formula showed an inverse association. Among diabetic-population-control pairs IgA antibodies to cow's milk formula were associated with an increased risk of IDDM independently of other cow's milk antibodies. When infant feeding patterns, milk consumption and ICA were taken into account in the analyses, high IgA and low IgM antibodies to cow's milk formula remained independently associated with an enhanced risk of IDDM among diabetic-siblingcontrol pairs. Among diabetic-population-control pairs high $\operatorname{IgA}$ antibody titres to cow's milk formula were, independently of other cow's milk antibodies and dietary variables, associated with an increased risk of IDDM. The fact that only some of the antibody titres were significant in the logistic regression models where also dietary variables were included may be related to differences in the amount of measurement error in these variables. Our findings in diabetic-sibling-control and diabetic-population-control pairs are at variance with the Swedish study, in which high $\operatorname{IgA}$ antibody titres to BLG were, independently of other cow's milk antibodies and formula feeding, associated with increased risk of IDDM [5].

Although the associations between enhanced levels of IgA antibodies to cow's milk proteins and an increased risk of IDDM do not provide any evidence of a direct involvement of these cow's milk antibodies in the progressive beta-cell destruction characteristic of IDDM, there are some recent observations which indicate that as a possibility. A new islet cell antigen, p69 or ICA 69 , has been characterized and there are several stretches of this protein which show considerable molecular homology with BSA [26]. Affinity purified BSA antibodies have also been shown to bind to a beta-cell membrane protein [27], which is obviously identical to $\mathrm{p} 69$. A pathogenetic model for IDDM has been developed based on early exposure to cow's milk proteins, including BSA, in genetically susceptible individuals resulting in the formation of immunological memory cells sensitized to antigenic epitopes of BSA [28]. Although this model is still speculative, it favours the view that the increased levels of antibodies to cow's milk proteins observed may represent a cross-reactive immune response reflecting ongoing beta-cell destruction. This is supported by the observed associ- ations between ICA and antibodies to cow's milk proteins.

Surprisingly few differences were observed in infant feeding patterns between diabetic children and their sibling-control children. The lack of significant associations between the infant feeding variables and the risk of IDDM in the present diabetic-population-control population was due to the small number of populationcontrol children in whom cow's milk antibodies were measured.

We did not observe any differences in current milk consumption between diabetic and sibling-control children or between diabetic and population-control children. The large amounts of milk, on average about $500-600 \mathrm{~g}$ daily, consumed by these children may explain why it is not likely to find any differences between the groups. The consumption of other milk products than milk or sour milk or foods containing milk were not included in the present study. The total daily consumption of milk and milk products by Finnish 3- to 12 year-old children was about $700 \mathrm{~g}$ in 1980 [29]. In Swedish children, an inverse association was found between the frequency of milk consumption and the risk of IDDM [30]. A positive ecological correlation has been observed between cow's milk consumption and incidence of IDDM in several western countries [31,32].

Our results suggest that both the age at introduction of dairy products and the amount of milk consumed during childhood affect the levels of cow's milk antibodies in all three populations studied. Of the cow's milk antibodies, high IgA antibodies to cow's milk formula were independently associated with increased risk of IDDM both among diabetic-sibling-control and diabetic-population-control pairs when infant feeding patterns, current milk consumption and in diabetic-sibling-control pairs also ICA were taken into account.

Acknowledgements. This study was supported by the National Institutes of Health, USA (NIH grant DK-37957, H. K. Akerblom and J. Tuomilehto), the National Research Council for Agriculture and Forestry of the Academy of Finland, Wilhelm and Else Stockmann's Stiftelse, the Nordisk Insulin Foundation Committee, the Association of Finnish Life Insurance Companies and the University of Helsinki. We express our gratitude to the children, parents and diabetes nurses who participated in the study. The "Childhood Diabetes in Finland" Study Group: Principal investigators H. K. Åkerblom and J. Tuomilehto; Coordinators R.Lounamaa, L. Toivanen, E. A. Kaprio; Data management J. Pitkäniemi, E. Virtala; Local investigators: A. Fagerlund, M.v.Flittner, B. Gustafsson, C. Häggqvist, A. Hakulinen, L. Herva, P.Hiltunen, T.Huhtamäki, N.-P.Huttunen, T.Huupponen, M.Hyttinen, T. Joki, R. Jokisalo, M.-L. Käär, S. Kallio, E.A.Kaprio, U.Kaski, M.Knip, L.Laine, J.Lappalainen, J. Mäenpää, A.-L. Mäkelä, K.Niemi, A.Niiranen, P.Ojajärvi, T.Otonkoski, K.Pihlajamäki, S.Pöntynen, J.Rajantie, J.Sankala, J. Schumacher, M. Sillanpää, M.-R. Ståhlberg, C.-H. Stråhlmann, T. Uotila, M. Väre, P. Varimo. 


\section{References}

1. Borch-Johnsen K, Mandrup-Poulsen T, Zachau-Christiansen B et al. (1984) Relation between breast-feeding and incidence rates of insulin-dependent diabetes mellitus. Lancet II: $1083-1086$

2. Kyvik KO, Green A, Svendsen A, Mortensen K (1992) Breast feeding and the development of type 1 diabetes mellitus. Diabetic Med 9: 233-235

3. Virtanen SM, Räsänen L, Aro A et al. (1991) Infant feeding in Finnish children $<7 \mathrm{yr}$ of age with newly diagnosed IDDM. Diabetes Care 14: 415-417

4. Kostraba JN, Dorman JS, LaPorte RE et al. (1992) Early infant diet and risk of IDDM in blacks and whites. Diabetes Care 15:626-631

5. Dahlquist G, Savilahti E, Landin-Olsson M (1992) An increased level of antibodies to $\beta$-lactoglobulin is a risk determinant for early-onset type 1 (insulin-dependent) diabetes mellitus independent of islet cell antibodies and early introduction of cow's milk. Diabetologia 35: 980-984

6. Virtanen SM, Räsänen L, Aro A et al. (1992) Feeding in infancy and the risk of type 1 diabetes mellitus in Finnish children. Diabetic Med 9:815-819

7. Kostraba JN, Cruickshanks KJ, Lawler-Heavner J et al. (1993). Early exposure to cow's milk and solid foods in infancy, genetic predisposition, and risk of IDDM. Diabetes 42: 288-295

8. Virtanen SM, Räsänen L, Ylönen K et al. (1993) Early introduction of dairy products associated with increased risk of IDDM in Finnish children. Diabetes 42: (in press)

9. Elliott RB, Martin JM (1984) Dietary protein: a trigger of insulin-dependent diabetes in the BB rat? Diabetologia 26: 297-299

10. Daneman D, Fishman L, Clarson C, Martin JM (1987) Dietary triggers of insulin-dependent diabetes in the BB rat. Diabetes Res 5: 93-97

11. Savilahti E, Åkerblom HK, Tainio V-M, Koskimies S (1988) Children with newly diagnosed insulin dependent diabetes mellitus have increased levels of cow's milk antibodies. Diabetes Res 7: 137-140

12. Karjalainen J, Martin JM, Knip Met al. (1992) Evidence for a bovine albumin peptide as candidate trigger of type 1 diabetes. N Engl J Med 327: 302-307

13. Savilahti E, Saukkonen TT, Virtala ET, Tuomilehto J, Åkerblom HK, the "Childhood Diabetes in Finland" Study Group (1993) Increased levels of cow's milk and $\beta$-lactoglobulin antibodies in young children with newly diagnosed IDDM. Diabetes Care 16: 984-989

14. Tuomilehto J, Lounamaa R, Tuomilehto-Wolf E et al. (1992) Epidemiology of childhood diabetes mellitus in Finland background of a nationwide study of type 1 (insulin-dependent) diabetes mellitus. Diabetologia 35: 70-76

15. Karjalainen J, Saukkonen T, Savilahti E, Dosch H-M (1992) Disease-associated anti-bovine serum albumin antibodies in type 1 (insulin-dependent) diabetes mellitus are detected by particle concentration fluoroimmunoassay, and not by enzyme linked immunoassay. Diabetologia 35: 985-990

16. Bottazzo GF, Dean BM, Gorsuch AN, Cudworth AG, Doniach D (1980) Complement-fixing islet cell antobodies in type 1 diabetes: possible monitors of active beta-cell demage. Lancet I: $668-672$
17. Knip M, Vähäsalo P, Karjalainen J, Lounamaa R, Åkerblom HK, the Study Group on Childhood Diabetes in Finland (1993) Characterization of the prediabetic phase in siblings of children with newly diagnosed IDDM. Pediatr Adolesc Endocrinol 23: 56-64

18. Lernmark $\AA$, Molenaar JL, van Beers WAMet al. (1991) The fourth international serum exchange workshop to standardize cytoplasmic islet cell antibodies. Diabetologia 34 : $534-535$

19. Karjalainen J, Knip M, Mustonen A, Åkerblom HK (1988) Insulin autoantibodies at the clinical manifestation of insulin-dependent diabetes - a poor predictor of clinical course and antibody response to exogenous insulin. Diabetologia 31: 129-133

20. Kletter B, Gery I, Freier S, Davies AM (1971) Immune responses of normal infants to cow milk. Int Arch Allergy 40: 656-666

21. Fälth-Magnusson K, Kjellman N-IM, Magnusson K-E (1988) Antibodies IgG, IgA, and IgM to food antigens during the first 18 months of life in relation to feeding and development of atopic disease. J Allergy Clin Immunol 81: 743-749

22. Tainio V-M, Savilahti E, Arjomaa P, Salmenperä L, Perheentupa J, Siimes MA (1988) Plasma antibodies to cow's milk are increased by early weaning and consumption of unmodified milk, but production of plasma IgA and IgM cow's milk antibodies is stimulated even during exclusive breast-feeding. Acta Paediatr Scand 77: 807-811

23. Harris MC, Kolski GB, Campbell DE, Deuber C, Marcus M, Douglas SD (1989) Ontogeny of the antibody response to cow milk proteins. Ann Allergy 63: 439-443

24. Avanzini MA, Plebani A, Monafo V et al. (1992) A comparison of secretory antibodies in breast-fed and formula-fed infants over the first six months of life. Acta Paediatr 81: 296-301

25. Husby S, Oxelius VA, Teisner B, Jensenius JC, Svehag SE (1985) Humoral immunity to dietary antigens in healthy adults: occurrence, isotype and IgG subclass distribution of serum antibodies to protein antigens. Int Arch Allergy Appl Immunol 77: 416-422

26. Pietropaolo M, Castano L, Babu S et al. (1993) Islet cell autoantigen $69 \mathrm{kDa}$ (ICA69): molecular cloning and characterization of a novel diabetes associated autoantigen. J Clin Invest 92: 359-371

27. Glerum M, Robinson BH, Martin JM (1989) Could bovine serum albumin be the initiating antigen ultimately responsible for the development of insulin-dependent diabetes mellitus? Diabetes Res 10: 103-107

28. Dosch HM, Karjalainen J, Morkowski J, Martin JM, Robinson BH (1992) Nutritional triggers of IDDM. Pediatr Adolesc Endocrinol 21: 202-217

29. Räsänen L, Ahola M, Kara R, Uhari M (1985) Atherosclerosis precursors in Finnish children and adolescents. VIII. Food consumption and nutrient intakes. Acta Paediatr Scand 318 [Suppl]: 135-153

30. Dahlquist G, Blom L, Persson L-Å, Sandström A, Wall S (1990) Dietary factors and the risk of developing insulin-dependent diabetes in childhood. BMJ 300: 1302-1306

31. Scott FW (1990) Cow milk and insulin-dependent diabetes mellitus: is there a relationship? Am J Clin Nutr 51: 489-491

32. Dahl-Jørgensen K, Joner G, Hanssen KF (1991) Relationship between cow's milk consumption and incidence of IDDM in childhood. Diabetes Care 14: 1081-1083 